\title{
OLD AGE AND POVERTY IN POLAND, 1945-1989: THE STATUS REGARDING KNOWLEDGE AND RESEARCH PROBLEMS
}

The history of old age has only relatively recently become explored as a research topic in Poland. This sketch focuses on the relationship between old age and poverty in People's Republic of Poland. Old age, however, was a significant object of interest of the PRL authorities in at least two aspects. The first was the social security system, particularly in relation to old age and disability pensions, and the second, social care for the aged.

Keywords: poverty, old age, People's Republic of Poland, social security system.

doi:10.2478/sho-2014-0003

The history of poverty in post-World War II Poland has already aroused some measure of interest among historians. ${ }^{1}$. However, the history of old age, which constitutes the focus of numerous western academics, has only relatively recently become explored as a research topic in Poland. ${ }^{2}$

Any attempt at addressing the relationship between old age and poverty in Poland (notionally called the People's Republic of Poland -

${ }^{1}$ E. Tarkowska (Ed.), Przeciw biedzie. Programy, pomysty, inicjatywy, Warszawa 2002; M. Przeniosły (Ed.), Dobroczynność i pomoc społeczna na ziemiach polskich w XIX, XX i na początku XXI wieku, Vol. 1, Kielce 2008; M. Przeniosły (Ed.), Dobroczynność i pomoc społeczna na ziemiach polskich w XIX, XX i na początku XXI wieku, Vol. 2, Kielce 2010; G. Miernik (Ed.), Bieda w Polsce, Kielce 2012; D. Jarosz, Polska bieda 1944-1956 - trudności i możliwości badawcze, Roczniki Dziejów Społecznych i Gospodarczych, Vol. LX / 2000, pp. 35-50.

2 This can be gauged above all by the academic conferences organised by the Historical Institute of Warsaw University:(9 -10 February 2012) and "Ludzie starzy w rodzinie i społeczeństwie na ziemiach polskich od XVIII do XX wieku (na tle porównawczym). Zmiany oceny wartości i prestiżu starości i młodości w XIX i XX wieku", (30 January - 1 February 2013). 
PRL) encounters obstacles, chief of which is a lack of historical studies. Comprehensive sociological research into PRL senior citizens were also none too frequent. Such a research project was carried out for the first time in the PRL by a team supervised by Jerzy Piotrowski around the end of 1967. ${ }^{3}$ In the later period, such studies were of a much smaller scale and usually addressed a limited number of issues. ${ }^{4}$

Old age, however, was a significant object of interest of the PRL authorities in at least two aspects. The first was the social security system, particularly in relation to old age and disability pensions, and the second, social care for the aged. It was especially this first aspect that generated numerous expert surveys, analyses, reports, whose number typically increased in periods preceding the introduction of successive benefits and changes in the national insurance system. For this reason, both in published studies and unpublished source materials produced by state institutions and the governing party, much interesting information can be found on the material situation of those drawing retirement and disability pensions. But can conclusions be drawn on the poverty of elderly people on the basis of these sources? Caution in this respect should stem above all from the fact that the relationship between old age and the status of an old age or disability pensioner was subject to significant changes. Beginning from the end of the 1970s, the age of people entitled to retirement and disability benefits was sharply reduced, due to the amended rules on early retirement; in 1984, the percentage indicator for female pensioners under sixty years of age came to over $30 \%$, and for men of up to 64 years of age, it was $44.4 \%$. (A further rise in the group of "young pensioners" was caused by the rules reducing the retirement age for miners and those employed in so-called special conditions) $)^{5}$.

Moreover, according to what has been established by specialists engaged in analysing PRL social security arrangements, up to the mid-1970s elderly people embraced by the pension system were in the minority; but what went unmentioned was that the level of benefits as a rule did not give those beneficiaries a basis for material survival. Estimates show that, in 1960, about $37 \%$ of the population drew pensions of one sort or another; in 1970, this figure rose to $40 \%$; in 1978 , about $50 \%$ of this group were

\footnotetext{
${ }^{3}$ J. Piotrowski et al [in:] Miejsce człowieka starego w rodzinie i społeczeństwie, Warszawa 1973.

${ }^{4}$ Their repetition in comparable scope to those of the 1960s occurred only after the political transformations of 1989; B. Synak (Ed.), Polska starość, Gdańsk 2003.

${ }^{5}$ W. Muszalski, Zatrudnienie a ubezpieczenie społeczne, Warszawa 1992, pp. 150-151.
} 
of a "post-productive" (i.e. retirement) age ${ }^{6}$ (and $27 \%$ of the population of that age maintained itself through paid work). Michał Winiewski maintains that towards the end of 1980, pensions were being drawn by nearly $60 \%$ of those classified as belonging to this (post-productive age) group. ${ }^{7}$ Sample research of the Central Statistical Office (GUS) of 1989, embracing people of sixty and above (hence a category defined otherwise than that in the earlier quoted research studies) showed on the other hand that $54.8 \%$ of them maintained themselves out of their old age pensions and $25 \%$ out of disability pensions. (In 1985 in similar studies, the corresponding figures were $50.4 \%$ and $25.3 \%$ ); and in these overall figures, $11 \%$ maintained themselves from their agricultural old age pensions, and $17.5 \%$ from their own work (of whom $12.4 \%$ had their own individual farms). ${ }^{8}$

The reason that most of the elderly relied on the social security system by the 1980s was because farmers were drawing disability pensions and more people were living longer. Insofar as in 1963 this group of beneficiaries accounted for $0.01 \%$ of the total rural population of a post-productive age, by 1982 it has risen to $28.9 \%$, and in 1989 it stood at $62.8 \% .{ }^{9}$

However, the reservations stemming from the facts established above do not signify that the search for interdependence between old age and poverty or, more broadly, the material situation of individuals, should not take into account the categories of old age and disability pensioners. In line with the universalisation of social security, most old people were part of the system. With due regard to these reservations, they can constitute an important supplement to direct research on the topic of the elderly.

The status of research, thus characterised, means that the scope of poverty affecting senior citizens in PRL cannot be restricted to what was established by sociologists, statisticians or social policy specialists. Otherwise it would be impossible to establish any reliable data for the period between 1945 and 1956 when virtually no such analyses were made. In this way we would also not learn much about the daily life of old people and about the emotions their material environment evoked.

The opportunity to comment on these topics is given by research into little known archival materials of an official character and personal docu-

\footnotetext{
${ }^{6}$ Women -60 and above, men -65 and above.

${ }^{7}$ L. Mackiewicz-Golnik, Powszechne ubezpieczenie emerytalne. Aspekty ekonomiczne i problemy finansowania, Warszawa 1983, pp. 23-25.

8 Sytuacja bytowa ludzi starszych w 1989, Warszawa 1990, p. 1 i n.

${ }^{9}$ J. Łopato, Spoteczna kwestia ludzi starych na wsi, [in:] B. Rysz-Kowalczyk: Społeczne kwestie starości. Wybór i opracowanie, Warszawa 1991, table. 6, p. 52.
} 
ments - letters and complaints sent to various state and party authorities. Although the latter, due to their specific character, demand a rigorous critical approach so as to shield against the allegation of viewing matters according to today's standards; at the same time it often gives the unique chance of a close "eye-witness", grass-roots encounter with an historical micro-world. For the same reasons, an analysis of press reports and commentaries also proved fruitful.

The character of the sources utilised has found expression in the structure of this study which I have adopted. Its first part attempts to resolve the issue posed in the title with the use of quantitative indicators, i.e. primarily the results of the earlier mentioned research studies, enhanced at times by numerical data discovered in the course of my archival inquiries. The second part is an attempt at a micro-history of poverty of old aged people in PRL, based mainly on personal documents.

\section{OLD AGE AND POVERTY: QUATITATIVE MEASURES}

Before fixing the basic facts of indigence among old people, it seems essential to point out that, as a rule, this group continually increased in number in post-war Poland. The percentage indicators for people aged 60 and above in 1948 was 8.8, in 1950 - 8.2 (this exceptional drop stemmed from post-war compensatory demographic processes), in 1960 - 9.6, in $1970-12.9$, in $1980-13.3$ and in 1990 - 16.6.10 The aging process of Polish society occurred at different rates in rural and urban areas: insofar as in 1950 over 854.000 of those aged 65 and above lived in rural areas, i.e. 5.4\% of the total rural population, in 1987 these indicators stood at $11.4 \%$ or 1689000 people. For urban areas, the corresponding indicators were the following: in $1950-5.0 \%$ or 463000 , and in $1987-8.4 \%$ or $1.937 .000 .{ }^{11}$ As can be deduced from the figures, with the passage of time, old age in Poland was becoming a dominant phenomenon in towns. This stemmed

${ }^{10}$ R. Synyka (Ed.), Polska starość. Praca zbiorowa, Gdańsk 2003, p. 12, table 1.1; Rocznik Demograficzny 1967-1968, Warszawa 1969, pp. 74-75, table 15; Rocznik Statystyczny 1957, Warszawa 1957, p. 20, table 12; Rocznik Demograficzny 1945-1968, Warszawa, 1968, pp. 5455, table 14-15; Rocznik Statystyczny 1950, Warszawa 1951, p. 17, table 7; Rocznik Statystyczny 1947, Warszawa 1947, p. 19, tables 6 and 7.

11 J. Łopato, Społeczna kwestia ludzi starych na wsi, [in:] B. Rysz-Kowalczyl (Ed.), Społeczne kwestie starości. Wybór i opracowanie, Warszawa 1991, p. 40, table 1. 
from a number of factors of a socio-political and economic nature, above all from the mass migration to towns. Up to the 1970s, migrants "rejuvenated" urban populations; later, upon reaching retirement age, they impacted on its aging. Between 1950 and 1985, the number of people 60 and above almost quadrupled in towns (from $0.6 \mathrm{~m}$. to $2.4 \mathrm{~m}$.), while in the countryside the increase was not quite double (from $1.1 \mathrm{~m}$. to $2.1 \mathrm{~m}$.). This did not affect the durability of the trend according to which the age indicator (the ratio of elderly to the overall population) was throughout this whole period lower in urban than in rural areas, and as the years went by, this gap widened. ${ }^{12}$ In demographic terms, post-war resettlement processes also resulted in the lowest number of elderly in the so-called Regained Territories. Conversely, the agrarian provinces of eastern Poland had the highest. ${ }^{13}$

Finally, it is worth mentioning that old age in PRL was above all a female experience. In 1990, people of 65 and older constituted $12.2 \%$ of the entire population, but for the female population as such this indicator stood at $14.7 \%$, while for men it was $9.6 \% .^{14}$

What is known about the situation of this ever increasing social group? What proportion of elderly people in PRL suffered poverty? For the 1940s and 1950s, as already mentioned, we have no research findings on this topic, apart from one survey carried out in 1948 by the Polish Institute of Social Services in Łódź with the active participation of the Faculty of Social Policy and Social Legislation of Łódź University in Warsaw (carried out in the Ochota district of Warsaw, which was based in 457 interviews) and Łódź (Chojny district - 530 interviews). The surveys also encompassed disability pensioners as well as people drawing so-called provisions (benefits) since before the war. (For the avoidance of complications both categories are referred to as disability pensioners). Most of them were elderly people.

They ascertained that the situation of those living alone was particularly difficult, even dramatic: "Their level of subsistence corresponds to that

\footnotetext{
12 W. Kondrat, Demograficzne aspekty starzenia się ludności Polski, in B. Wójcik (Ed.), Warunki życia i problemy ludzi starych, Warszawa 1986, p. 148.

${ }^{13}$ R. Rybiński, Ziemie Zachodnie i Pótnocne w pótwieczu 1945-1995, Torun 1997, pp. 3543; GUS, Departament Badań Demograficznych i Społecznych, Sytuacja ludzi starszych, kwiecień 1982, p. 19; W. Kondrat, op. cit., p. 143; L. Frąckiewicz, Karta praw człowieka starego, Warszawa 1985, pp. 26-27; J. Łopato, Spoteczna kwestia ludzi starych na wsi, [in:] B. RyszKowalczyk (Ed.), Społeczne kwestie starości. Wybór i opracowanie, Warszawa 1991, p. 44, table 3.
}

${ }^{14}$ Polska starość..., p. 12, table 1.1. 
of a vegetative existence with their exceptionally meagre nutrition failing to satisfy their most basic needs. The situation of these individuals is not improving much when - as was the case in Łódź - they have their own houses and when a couple on disability pensions live together. People ill, handicapped or crippled and in need of full-time care also belong to this particularly disadvantaged group. The so-called supplement that some disabled receive does not begin to meet their increased needs." 15 Due to poverty, the considerable majority of the elderly people included in the research - men (invalids on disability pensions) - maintained themselves by gainful employment even after their 70th birthday (Warsaw 61.9\%, Łódź $-64.1 \%$ ) and usually continued in the occupations they had up to retirement. A similar tendency occurred among women, but wage earning by those over 70 was rare. Most of those women changed their occupation, transferring to lighter and irregular occupations, ad hoc trades or part-time employment. ${ }^{16}$

The comprehensive research into the material situation of elderly people (aged 65 and above) carried out around the beginning of 1967, as already mentioned, established that $48 \%$ had a farmstead as their source of income, and $45 \%$ drew pension benefits. As a group, they had four main sources of income: disability pensions (42\%), income from a farm $(40 \%)$, help from children $(7 \%)$, and income from work other than on the farm (7\%). Among the population not tied down to farmsteads, the dominant positions $(71 \%)$ were taken by disability pensions followed by income from labour (11\%) and help from children (10\%). In the agricultural community, income from farming was the main source of income for $84 \%$ of its members; for $8 \%$ it was their disability or retirement pensions, and for $4 \%$ it was help from children. One in five of the respondents declared income from two sources, and one in a hundred from three or more sources. Low disability and retirement pension rates ensured that they were not the exclusive - and in many cases not even the main - sources of income for pensioners: $33 \%$ of these beneficiaries had other revenue streams in addition to their pensions. These other sources were chiefly help from children, income from their farmsteads and from their own labour other than on the farm.

15 W. Szubert, Badania nad społeczna rola rent ubezpieczeniowych, Studia i materiały z historii ubezpieczeń społecznych w Polsce, Vol. 3 / 1985, p. 106.

16 W. Szubert, Niektóre zagadnienia rent starczych w świetle badań z 1948 r., Przegląd Ubezpieczeń Społecznych, no. 4 / 1950, pp. 36-40. 
The quoted research findings revealed a worrying phenomenon, namely the existence of a sizeable group of elderly people without any monetary income $(13 \%)$ of indeterminate income $(20 \%)$. They confirmed the rule (about which researchers into the material situation of old age pensioners in PRL also wrote) of the decline in income of respondents as they aged. ${ }^{17}$

In 1979, GUS, together with the Institute of Social Economy (IGS), analysed over 1000 urban residents of "post-production" age - women (60+) and men $(65+)$. It turned out that, for three quarters of them, the basic means of survival was one's own disability or old age pension; one eighth was supported by their spouses (usually women by men on disability or old age pension). In total, about $90 \%$ were persons dependent on income from one type of pension or another. Only 5\% drew their main source of income from work, and $17 \%$ admitted that they had some additional occupation. An analysis of household income of older people on a per capita basis revealed that every twenty-fifth household had such low income that it did not even cover the "biological minimum". In another researched group, $45 \%$ of respondents found themselves below the social minimum. The material situation of nearly half of the elderly people analysed was thus difficult and, with that, clearly worse among persons kept by their spouses (low supplements for non-working wives) or by other household members. ${ }^{18}$

Some significant information about the household budgets of elderly people was gleaned from GUS research. Chronologically, the last of these was carried out in 1988, before the change of the political regime. It revealed that $8 \%$ of elderly people belonged to the group of low income households (up to 22000 zlotys per month); in 1985 a similar indicator (income criteria - up to 6000 zlotys per month) came to $20.1 \%$. Income achieved by married couples working together with their grandchildren $(32.2 \%)$ and elderly people kept by their husbands or wives $(19.9 \%)$ or by their children (14.3\%) and older people from peasant households (11.2\%) was particularly low. ${ }^{19}$

This less than optimistic picture is confirmed by research concerning the so-called social minimum of old age and disability pensioner households.

17 J. Nadolski, Sytuacja materialna ludzi starszych, [in:] J. Piotrowski et al., op. cit., pp. 314-333.

18 A. Tymowski, Sytuacja materialna, in: Sytuacja życiowa osób starszych, GUS Zakład Badań Statystyczno-Ekonomicznych, vol. 127, Warszawa 1982, pp. 61-62.

19 Sytuacja bytowa..., p. XXVI. 
According to Andrzej Tymowski's findings, still back in 1966, over 70\% of the old age pensions did not cover the social minimum as calculated for that year. Some improvement in this regard was noted after the pension system reform in 1968. This meant that at the beginning of the 1970s, when a huge number of people retired at the time - nine out of ten had it awarded at a level guaranteeing them satisfaction of their basic needs, but only one in five old age pensioners of 1958 and earlier had benefits exceeding the social minimum level of $1970 .{ }^{20}$

According to Michał Winiewski's research in 1975, nearly two thirds of those on retirement or disability pensions were in receipt of benefits below the existential social minimum. What made the situation even worse was the fact that a significant number of people - though impossible to establish with precision - supported another person out of such low pensions. It was in their families - apart from large families and single-parent families, as well as victims of fate - that poverty was concentrated. ${ }^{21}$

Other research estimates put the indicator of old age and disability pensioners with inadequate regular income in 1975 at 54.6\%, in 1980 at $38.8 \%$, in 1982 at $40.6 \%$, and in 1983 at 59.3\%. The corresponding indicators for working people were the following: $16.4 \%, 13.8 \%, 26.9 \%$ and $32 \% .22$

A detailed listing of people on low income in various households in 1980-1989, in percentages, is given in Table 1; the figures are based on GUS statistics compiled by reference to the sample households used in analysing family budgets.

As can be seen, the indicators for old age and disability pensioner households fluctuated regarding per capita income below the social minimum, but in the years 1981-1986 it amounted to at least $23 \%$ of their total number. The quoted research studies clearly show that the bottom of the trough during the crisis, in terms of income in the final decade of PRL, came in 1983.

What is important to underscore is that during the years 1981-1985, the household income of those on retirement or disability pensions was not 97.

20 A. Tymowski, Minimum socjalne. Metodyka i próba określenia, Warszawa 1973, pp. 95-

${ }^{21}$ L. Frąckiewicz, Karta praw..., pp. 90-91; H. Balicka-Kozłowska, Sytuacja życiowa i potrzeby ludności starszej, Instytut Pracy i Spraw Socjalnych. Studia i materiały, vol. 7, Warszawa 1979, pp. 20-22.

${ }^{22}$ L. Deniszczuk, Minimum socjalne i minimum kryzysowe a warunki życia rodzin robotniczych, [in:] P. Wójcik (Ed.), Warunki bytu robotników, Warszawa 1984, p. 221; B. Szopa, Podziat dochodów a poziom życia ludności (na przykładzie Polski), Kraków 1994, p. 73, table 12. 
Table 1. Proportion of people of low per capita income according to type of household in Poland in 1980-1989

\begin{tabular}{|c|c|c|c|c|c|c|}
\hline \multirow[b]{2}{*}{ Year } & \multirow[b]{2}{*}{$\begin{array}{l}\text { Low in- } \\
\text { come in } \\
\text { ‘000s zlo- } \\
\text { tys }\end{array}$} & \multicolumn{5}{|c|}{ Households } \\
\hline & & Total & Workers & $\begin{array}{l}\text { Worker- } \\
\text { peasants- }\end{array}$ & Peasants & $\begin{array}{l}\text { Old age } \\
\text { and disa- } \\
\text { bility pen- } \\
\text { sioners }\end{array}$ \\
\hline 1980 & 2.0 & . & 15.8 & 30.2 & 33.3 & 30.6 \\
\hline 1981 & 2.5 & 14.2 & 10.6 & 16.4 & 16.9 & 23.3 \\
\hline 1982 & 5.0 & 20.0 & 16.8 & 22.1 & 21.7 & 27.7 \\
\hline 1983 & 6.0 & 27.2 & 22.3 & 25.0 & 31.9 & 40.9 \\
\hline 1984 & 7.0 & 24.4 & 19.6 & 23.7 & 33.0 & 37.7 \\
\hline 1985 & 8.0 & 22.6 & 18.5 & 21.1 & 30.3 & 34.9 \\
\hline 1986 & 9.5 & 21,3 & 17.9 & 20.6 & 29.8 & 29.9 \\
\hline 1987 & 12.0 & 25.3 & 24.1 & 23.9 & 31.9 & 26.9 \\
\hline 1988 & 20.0 & 20.0 & 17.9 & 16.6 & 24.9 & 28.4 \\
\hline 1989 & 70.0 & 16.3 & 13.7 & 12.3 & 22.3 & 26.4 \\
\hline
\end{tabular}

Source: B. Szopa, Podział dochodów a poziom życia ludności (na przykładzie Polski), Kraków 1994, p. 74, tab. 13; J. Kordos, Pomiar ubóstwa w Polsce, Wiadomości Statystyczne, no. 11 / 1991, p. 4; H. Góralska, Sytuacja materialna emerytów i rencistów w latach osiemdziesiątych, [in:] P. Wójcik (Ed.), Warunki życia i problemy ludzi starych, Warszawa 1986, pp. 391-395; Archiwum Akt nowych (further: AAN), Komitet Centralny Polskiej Zjednoczonej Partii Robotniczej (further: KC PZPR), Wydział Polityki Społeczno-Ekonomicznej LXX/133, Stanowisko Komisji Polityki Społecznej i Ochrony Zdrowia KC PZPR do opracowania pt. "Warunki życia ludności w latach 1981-1986", Warszawa 21 May 1987, k. 157; Zróżnicowanie dochodów kosztów utrzymania i spożycia w 1980 r., Warszawa 1981, p. 27; Warunki życia ludności w latach 1981-1985, Warszawa 1986, pp. 32-33.

only lower than that of workers, but, as a rule, the gap between them was widening ever more. In 1981, the income of the former was $80 \%$ of the income of the latter; in 1982, it was $84.5 \%$ (which was linked with the award of compensation for price rises in food, fuel and energy from 1 February 1982); in 1983, it was $80.2 \%$; in $1984-79.1 \%$; and in $1985-78.6 \% .{ }^{23}$

${ }^{23}$ H. Góralska, Sytuacja materialna emerytów... , pp. 391-395. According to Lidia Beskid's estimates (see: Ekonomiczny i społeczny wymiar przemian warunków życia w latach 1980-1985, in collective work: L. Beskid, ed., Warunki i sposób życia - zachowania przystosowawcze w kryzysie, Warszawa 1989, p. 40), per capita income in old age and disability pensioner households in 1973 was $88 \%$ of the income of blue collar workers, in 1975 - it was $83 \%$, in $1978-87 \%, 1980-90 \%, 1981-86 \%, 1982-89 \%, 1983-84 \%, 1984-84 \%$ and in 1985 $-84 \%$. 
The material situation conditioned primarily the structure of expenses of senior citizens during PRL. Research carried out by GUS at the end of 1971 into the household budgets of old age and disability pensioners showed that, on average, $56.7 \%$ of income was spent on food, $10 \%$ was allocated to expenses associated with furnishing and maintaining one's accommodation in good repair, $9.6 \%$ was spent on clothes and footwear, $6.6 \%$ went on lighting and heating, $5.7 \%$ on culture, education, sport, tourism and leisure, and $4.2 \%$ on personal hygiene and health protection. In the lowest income bracket, expenditure on food accounted for $65 \%$ of the total income. ${ }^{24}$

Improvement in the material condition of society as such, including that of old age and disability pensioners, during the Gierek era, also found expression in the structure of expenditure in the years that followed. Limiting ourselves to only the most important food items, as researched by GUS, it can be established that expenditure on food in this group of households in 1974-1975 came to 52-53\%, while in workers' households it was $34-36 \%$, in peasant households $-41-45 \%$, and in worker-peasant households $-38-40 \% .^{25}$

This positive tendency broke down in the 1980s. Still in 1981, expenditure on food in disabled and old age pensioner households accounted for $47.8 \%$ of the household budget, as compared to $36.5 \%$ in workers' households and $42 \%$ in worker-peasant households. ${ }^{26}$ However, in 1982, in disabled and old age pensioner households it rose to $57.3 \%$, in 1983 - to $54.4 \%$, in 1984 - to $55.1 \%$, and in 1985 it dropped to $54.8 \%$; the corresponding indicators for workers' households were: in $1982-50.8 \%, 1983-42.5 \%, 1984$ $-42.9 \%, 1985-42.7 \% .{ }^{27}$ A declining trend in consumption, towards a po-

${ }^{24}$ Budżety domowe rodzin emerytów i rencistów w roku 1971/72, Warszawa, June 1973, pp. 15-16.

${ }^{25}$ Zróżnicowanie wydatków konsumpcyjnych gospodarstw domowych w grupach społecznozawodowych w latach 1974-1975. Z Prac Zakładu Badan Statystyczno-Ekonomicznych, vol. 103, Warszawa 1978.

${ }^{26}$ L. Frąckiewicz, Karta praw..., p. 91.

${ }^{27}$ H. Góralska, Sytuacja materialna emerytów..., p. 397 et seq. Bogumiła Szopa presented a slightly different picture though generally in agreement regarding these tendencies in Podział dochodów a poziom życia ludności (na przykładzie Polski), Kraków 1994, p. 58, table 9. In her estimation, the percentage of expenditure on food, in 1988, among old age and disability pensioner households totalled $48,0 \%$, while in blue collar households it was $38.1 \%$ and in peasant households, 39\%; in 1989, the corresponding indicators were $58.7 \%, 45.8 \%$ and $45.3 \%$. Similar proportions in expenditure out of current income in 1988-1989 were revealed by the research of Zofia Zarzycka and Jan Więcek, Przemiany w konsumpcji gospo- 
sition of securing the bare essentials - which, in the first place, was driven by rising food prices - occurred during periods of economic crisis. ${ }^{28}$

The scale of poverty expressed in these estimates induced people to seek additional cheap sources of food. For this reason, as indicated by research results into life styles, in the years 1974-1982, income from cultivated allotments increased in pensioner households nine-fold, and in workers' households, fivefold. Their share in general revenues increased in the first group from $2 \%$ in 1974 to $4.3 \%$ in 1982, and in the second group - from 1.4 to $1.7 \%$. In 1982, the share of home-grown produce from allotments in food expenditure came to about $10 \%$ in old age pensioner households and $5.3 \%$ in workers' households (with the rider that in old age pensioner households whose members had not completed their primary school education, the figure was $20 \%$ ). At the same time, $17.4 \%$ of pensioner households and $16 \%$ of workers' households declared they bred animals for personal consumption. ${ }^{29}$.

The necessity of allocating such a large part of income to food fuelled the need to make savings elsewhere. For this reason, older people had problems in buying clothes and footwear. The only research that I am aware of dedicated exclusively to this problem was carried out in 1973 by GUS and the Institute of Internal Trade (based on a sample of households which included old age pensioners) revealed that old men on average owned 6.7 shirts, 2.4 suits, 2 pairs of trousers, and 1.9 jumpers, while women had 4.8 dresses, 4.3 blouses, 2.8 pairs of trousers, 2.1 jumpers, and 1.9 suits. Concerning heavy garments (coats, jackets), men and women owned one item per person. The average Polish old age pensioner had two

darstw domowych w Polsce w okresie transformacji (w latach 1988-1992), Łódź 1996, p. 50, attachment 11.

${ }^{28}$ L. Beskid, Ekonomiczny i społeczny..., pp. 23-24; R. Milic-Czerniak, Adaptacja konsumentów do warunków kryzysu ekonomiczno-społecznego w pierwszej połowie lat osiemdziesiątych, [in:] L. Beskid (Ed.), Warunki i sposób życia - zachowania przystosowawcze w kryzysie, Warszawa 1989, pp. 118-121.

${ }^{29}$ P. Gliński, Ekonomiczne aspekty życia codziennego, [in:] A. Siciński, ed., Style życia w miastach polskich, Ossolineum 1988, p. 286; R. Milic-Czerniak, Sposoby ochrony wzorów konsumpcji w miejskich gospodarstwach domowych w okresie kryzysu, [in:] L. Beskid (Ed.), Warunki życia i potrzeby społeczeństwa polskiego 1982: raport z badania, Warszawa 1984, p. 68. Somewhat different estimates have been made by Kazimiera Guraj-Kaczmarek and Zofia Zarzycka (see Dochody ludności w starszym wieku w Polsce na podstawie budżetów gospodarstw domowych, [in:] Wybrane uwarunkowania $i$ konsekwencje procesu starzenia się ludności Polski, Warszawa 1987, pp. 100-101). In their estimation, income from a cultivated plot in 1980 constituted $3.1 \%$, in 1981 it was 3.8\%, in $1982-4.6 \%$ and in $1983-7.3 \%$ of their total income in those years. 
Table 2. Installations in elderly people's housing $(65+)$ in 1978

\begin{tabular}{lccc}
\hline & total & Towns & Countryside \\
\hline $\begin{array}{l}\text { Persons of 65 years of age } \\
\text { and over (in ‘00s). }\end{array}$ & 3512 & 1793 & 1719 \\
\hline In housing equipped with & & Percentage & \\
\hline Water mains & 54.4 & 80.7 & 27.0 \\
\hline Toilet & 37.3 & 60.8 & 12.8 \\
\hline Bathroom & 36.2 & 54.4 & 17.1 \\
\hline Central heating & 25.4 & 39.2 & 11.0 \\
\hline Hot water & 31.8 & 47.3 & 15.7 \\
\hline Gas & 39.5 & 62.6 & 15.3 \\
\hline
\end{tabular}

Source: AAN, Rada ds. Ludzi Starszych, Inwalidów i Osób niepełnosprawnych (Council of Elderly People, Invalids and Disabled People) 1/44; D. Kozińska, Warunki mieszkaniowe seniorów (Housing conditions of senior citizens), [in:] "Ludzie starsi w Polsce, ich warunki i potrzeby", materials form conference organised by the Work Problems and Social Policy Committee of the Polish Academy of Arts and Sciences (PAN) and the Institute of Labour and Social Policy, Warsaw, 12 May 1982, pp. 287-298.

pairs of shoes at the most. ${ }^{30}$ Of course the numbers varied based on the type of household pensioners they belonged to. Nonetheless, the averages provide a clear picture of the day-to-day hardships of old people.

The poverty of elderly people also meant that they lived in worse conditions, as was already revealed by research in the 1960s. In the 1970s and 1980s, elderly people's housing standards, including the furnishings of their accommodation, improved. This can be deduced if only by reference to the general census of 1978 .

However, indicators regarding standards in fixtures and fittings were lower than for the population in general. In towns, the proportion of the population aged fifteen or more having in their homes mains water, a bathroom and central heating was respectively 8.3,16.1 and 17.0 higher than in the homes of senior citizens. Moreover, it is worth adding that in 1978, about three quarters of the general number of households headed by people aged sixty five or over had at their disposal self-contained housing accommodating only one household, while one quarter had to share their utility accommodation facilities with other households. ${ }^{31}$

30 Charakterystyka dochodów i stan posiadania odzieży i obuwia osób pobierających emeryturę, Warszawa, April 1974, Informacje GUS. Materiaty statystyczne, pp. 24-26.

31 AAN, Rada ds. Ludzi Starszych, Inwalidów i Osób niepełnosprawnych (Council of Elderly People, Invalids and Disabled People) 1/44; D. Kozińska, Warunki mieszkanio- 
According to research findings in 1985, 99\% of elderly people's households were connected to the power grid; $74 \%$ had mains water (in this, peasant households $-46.9 \%$, old age and disability pensioners $-80.1 \%$ ); $39.5 \%$ had central heating ( $24.4 \%$ and $40.3 \%$ ); $72.7 \%$ had their own kitchen sinks (44.6\% and $77.8 \%) ; 60.5 \%$ had their own indoor toilets $(31.3 \%$ and $65,7 \%) ; 54.4 \%$ had their own bathrooms (32.7\% and $56.2 \%) ; 55.1 \%$ were connected up to gas mains ( $25 \%$ and $60.7 \%$ ); and $14.4 \%$ had telephones $(3.3 \%$ and $17 \%)$. The most well off households in terms of furnishings were, in every respect, those of elderly people classified as white collar workers.

A further factor impacted on housing comfort levels: in 1984, every third household lived in accommodation built before 1945, but every second one of these pre-war housing units was occupied by older people. ${ }^{32}$

Research in the late 1970s also revealed that the feeling of pauperisation in old age was the root-cause of elderly people becoming more distant with their friends and unwilling to make new contacts. Their social worlds were shrinking as a result, frequently being restricted to their closest family members. When family relations deteriorated or were made difficult due to drifting apart, there remained the dominant and increasingly oppressive feeling of isolation which, not infrequently, was linked to abject poverty. ${ }^{33}$

\section{OLD AGE AND POVERTY - THE VIEW FROM BELOW}

How do old age and poverty show up in source materials in relation to specific individuals who experienced it? Besides the earlier mentioned letters, there is much interesting information on the subject to be found in

\footnotetext{
we seniorów (Housing conditions of senior citizens), [in:] "Ludzie starsi w Polsce, ich warunki i potrzeby", materials form conference organised by the Work Problems and Social Policy Committee of the Polish Academy of Arts and Sciences (PAN) and the Institute of Labour and Social Policy, Warsaw, 12 May 1982, pp. 287-298; for estimated figures on this topic for 1972, see Analiza wyników jednorazowego badania ankietowego warunków bytu ludności (Dochody. Warunki mieszkaniowe. Wyposażenie gospodarstw domowych w przedmioty trwałego użytkowania) 1972 r., Warszawa, June 1975, pp. 60-66.

32 D. Kozińska, A. Lutostańska, Gospodarstwa domowe prowadzone przez osoby w wieku 60 lat i więcej oraz ich warunki mieszkaniowe (w latach 1978 i 1984), [in:] Warunki życia i problemy..., pp. 445-453.

${ }^{33}$ H. Balicka-Kozłowska, Sytuacja życiowa..., pp. 23-24.
} 
the mass media. This source is particularly significant for the immediate post-war period because of the dearth of any other reliable sources on the difficult material situation of old people. Their fate became one of the featured topics of Polish journalism after 1956.

What are the most important contexts of perceiving poverty in old age in these types of popular communications?

\section{MAKING THE PUBLIC AWARE OF THE POVERTY}

Above all, from the 1940s, there are letters and press commentaries whose authors justified why their income (disability pension, retirement pension, earnings) was insufficient to assure them a bare minimum existence. Usually, to give credence to their arguments aimed at highlighting their degree of poverty, they enumerated the items in their household budgets in minute detail.

A text published in the periodical Emeryt (Pensioner), published by the Regional Union of Pensioners in Poznań in April 1947, could serve as an example of such public reportage. It spoke of the difficulties of even those families with increased benefits at the time (up to 2000 zlotys) in making ends meet. A letter to the editor from Gdynia containing information about the cost of living for two people, that is a pensioner and his wife, was used to illustrate the predicament. The calculation contained the following items: rent (one room plus the use of a shared kitchen) - 200 zlotys, services and utilities (water, gas, caretaker, chimney sweep etc.) - 200 zlotys, heating - 250 zlotys, electricity - 100 zlotys; food ("life"): bread 480 zlotys, potato soup ( $30 \times 2)-1800$ zlotys, tea substitute - 200 zlotys, sugar $2 \mathrm{~kg}$ 360 zlotys, laundry - 500 zlotys, soap - 100 zlotys, cotton, needles and thread - 100 zlotys, medicine - 200 zlotys, matches - 90 zlotys, hairdresser and other sundry expenses -75 zlotys. Total -4555 zlotys. The editor summed up this total by saying: "The editors apologise to the author for deleting from his computation the items concerning expenditure on cigarettes and newspapers because a pensioner does not have to either smoke or read newspapers." 34

In that letter of 1947 Zygmunt Wiśniowski wrote: "One of my old pensioner friends, who had worked for 36 years in the finance department (at

${ }^{34}$ Listy z kraju. Gdynia, Emeryt, Nr 8 / 1947. 
VII grade) so conscientiously and diligently that he could serve as an example for others, told me wistfully in a conversation we had in response to my remark that he had wasted away a good deal. That was because for a number of years he has been living only on bread, potatoes and unsweetened tea or milk,-because he cannot afford anything else. He is a lonely bachelor; he lives at his acquaintances who, out of the kindness of their hearts, let him have a room in their house at a minimal pre-war rent rate. Despite being 70, he would still like to work, e.g. as an accountant in some enterprise, but who today would employ an older person when younger ones are preferred. What a terrible fate in the final years of one's life!"35

This mode of presenting the scale of material destitution, by enumerating the basic items of the household budget, also frequently appeared later in the correspondence of old age and disability pensioners addressed to the authorities after each successive reform of the national insurance system. For example, in January 1956, Polish Radio received a letter signed "Pensioners" (which often lacked a postal stamp) whose authors wrote:

Sated and well-clothed Comrades. Give us something to eat. Do you know that destitute people are living next to you who are perishing because of malnutrition, hunger, destitution and cold? It is pensioners who have worked for almost the whole of their lives. Is there anyone who might show concern that, out of this derisory retirement pension of 200 or 300 zlotys, they have insufficient means to buy themselves potatoes or fuel for the winter or something warm? A jumper costs two months' pension. And shoes? Do you know that there are people who never eat meat, eggs, milk, cheese or fruit? That, as the year is long, public holidays or no, evenings and mornings, it's bread with black coffee, and at noon it's potatoes or gruel and borsch. That's every day, whole years at a stretch. Where is this social justice or care for fellow man? Before the war, Austria and Poland guaranteed pensioners a comfortable and secure old age, while the People's Republic increased pensions by 10 or 20 zlotys over two years ago. What was that supposed to be, some sort of joke? For the love of communism, give us food. We do not organise demonstrations and street riots; thus no one knows about our hunger and destitution, and there are people who earn so much that they do not know what to do with their money. Maybe the philanthropy of society could help the destitute if the people's state does not want to or cannot do so. Take pity, or herd us into a field and put an end to us. That would be a humanitarian act. ${ }^{36}$

To be sure, it seems that this type of message, countenancing extreme deprivation in food and clothing, did appear in source documents to the

35 Z. Wiśniowski, “Emeriti”, Emeryt, Nr 6 / 1947

${ }^{36}$ Archiwum Dokumentacji Aktowej TVSA (further: ADA), Komitet do spraw Radiofonii “Polskie Radio". Biuro Listów [“Polish Radio" Committee - Editors Office] (further: PR), 1050/15, bulletin no. 23, 19 April 1956. 
end of the period under analysis, but the incidence of drastic descriptions of destitution in old age was reduced in the 1970s and 1980s. This could have stemmed from an improvement in the material situation of senior citizens in PRL, though this requires additional research.

\section{OLD AGE POVERTY IN THE COUNTRYSIDE}

The pictures of old age poverty presented above concerned old age and disability pensioners in urban areas. However material destitution also affected the elderly in the countryside. Their situation was particularly difficult up to the moment of universalisation of the system of retirement and disability pensions for farmers (in exchange for signing over their land to the state or their beneficiaries), which occurred at an accelerated rate as from the end of the 1970s.

Up to then, the most frequent traditional form of social security for old farmers in the countryside was a personal maintenance contract for life, regulated before the war by the Code of Obligations of 1933, and after the war, by the Civil Code of 1964. It consisted of the owner of a farmstead - the would-be "annuitant" - obliging himself to transfer his right of ownership to another person in exchange for being maintained for life. Such a contract was usually signed between family members, in the form of a notarial deed (otherwise it was legally null and void), and it contained a detailed list of the obligations to be undertaken by the farmstead's purchaser. However, if no obligations were specified in the contract, it was taken to mean that the purchaser was obliged to accept the "annuitant" into his household, house him, clothe and feed him, and assure him of help and care in time of illness. Upon the death of the "annuitant" the contracting party had the duty to organise the "annuitant's" funeral in accordance with the local custom. ${ }^{37}$

In practice, "lifetime maintenance contracts" were breached as a matter of course. It is estimated that in the 1970 s about $50 \%$ of the lifetime maintenance contracts were not honoured, which found reflection in court claims concerning arrears in benefits. ${ }^{38}$ This became the topic of harrow-

${ }^{37}$ E. Spirydowicz, Ziemia i prawo, Warszawa 1977, pp. 107-110; A. Oleszko, Rola umów w stosunkach wiejskich w świetle praktyki sadowej i notarialnej, Warszawa 1988, pp. 25-27, 46, $72,76$.

${ }^{38}$ B. Tryfan, System emerytalny w opiniach ludności wiejskiej, Warszawa 1978, p. 6. 
ing reports. ${ }^{39}$ In one of them, titled "Łaskawy chleb" ("Gracious Bread", of 1969), placed in the volume Ziemia i ludzie, its author - Barbara Tryfan, wrote that "an old man... like of more than 200 years ago, so as not to die of hunger, usually signs his land over to his children and looks to them for their grace and favour in return. All too often, this is not "gracious bread", because in all district courts, one can find scores of cases involving old people deprived of the means to live, seeking maintenance from their children. One can find documents in bailiffs' records showing that court rulings were frequently disregarded and old people did not receive the maintenance due to them. Frequently, even previously good children changed radically after receiving a legacy." 40 She wrote in the same volume: "Lying in wait for a parental legacy, and disputes on the division of a household between siblings, frequently lead to very acute conflicts with simply tragic epilogues. On the other hand, parents afraid of a takeover in exchange for the promise of maintenance for life, hold on to their rights of ownership for dear life, even if that is against the interests of the household." 41

B. Tryfan quotes numerous examples of such conduct. Here is one particularly drastic example: "The claimant had signed over her plot of land to her son with the reservation of lifetime maintenance benefits. But her son did not want to cultivate it, and after a certain time he passed on the plot to a married couple along with the mother of course, who was part of the inventory, as it were. After a certain time, that couple also changed their minds and passed on the farmstead to another couple, obviously along with all the encumbrances, that is chiefly the mother of the respondent. In the space of a few years, this old lady, aged 93, 'changed her owner' three times, passing from hand to hand like an obtrusive chattel. Finally, the buyers failed to discharge their obligations, and the old lady simply suffered hunger." 42

The author of these reports also came across instances of crimes committed due to disputes over land. One of these dramas was played out in the district of Nowy Targ: "The point was to accelerate the transfer of ownership of land by Aniala R., the mother, to her daughters and son-in-law. Possessed by the desire to own the land which legally still belonged to

\footnotetext{
39 See, among others, the volumes of: Konflikt na wsi: reportaże, Warszawa 1980; J. Grabowicz Pejzaż wiejski z Temida, Warszawa 1965.

${ }^{40}$ B. Tryfan, Ziemia i ludzie, Warszawa 1971, p. 72.

41 Ibidem, p. 74.

42 Ibidem, p. 80.
} 
Aniela R., all four members of the family (i.e. her daughters, husband and son-in-law) took pains to besmirch her name in the village." They offered a neighbour 10000 zlotys to kill her. When he refused, they asked for his proxy in finding someone who would. He found Władysław P. "(who) lay in wait in the evening by the footbridge which was to be crossed by Aniela R. and to kill her on the spot with an axe. After that he returned home where he prayed long and earnestly that the dead woman would not come to haunt him at night. And thus, in the hope of receiving their acres quicker, which they had the use of anyway, the mother was killed." 43 Another crime caused by a dispute over the ownership of a farmstead in Luszawa, in the province of Lubelskie, was described by Józef Grabowicz. ${ }^{44}$

What is characteristic is that the Polish press of the 1960s was brimful of drastic stories of this type. Did similar cases not occur in later years? Most certainly they did, but it seems that the more universal reach of disability and old age pensions had a telling ameliorative effect on the tensions and conflicts engendered by older people seeking to secure their material basis for existence.

\section{OLD AGE, POVERTY AND LONELINESS}

The extant reports which attempted to record individual fates of PRL senior citizens, evinced yet another motif, which is linked to the feeling of poverty. It was the effect of two basic factors at play. On the one hand, the social security system caused a sharp decline in income stemming from enforced or voluntary retirement. On the other hand, there was a consumerist ratchet effect of a kind, namely the universal psychological mechanism whereby people, irrespective of the fluctuation in their income, tried to maintain their earlier attained level of consumption. When that became impossible, the common reaction was gradual reclusion and the limitation of social contacts. Elderly people, frequently not out of their own choice, became "family-centric". Family contacts, from the psychological point of view, played an ever more important role. At the same time, the enormous scale of various post-war migrations made family contacts more difficult to maintain. In such conditions, the most important "social ailment"

43 Ziemia i ludzie, [in:] B. Tryfan, Ziemia..., p. 156.

44 J. Grabowicz, Starość, [in:] Pejzaż wiejski..., pp. 159-172. 
of elderly people was loneliness which increased with the death of one's spouse. To be sure, this was confirmed by some of the earlier quoted research studies, but its linkage with the material degradation of senior citizens was not analysed in any greater depth.

And in this case too, PRL journalism allowed an upclose view of events. By way of example, at least one report, penned by Jerzy Lovell, might be worth quoting. His heroine was "an old woman with matches" - named Regina, residing in a block of flats in Nowa Huta, who was prematurely widowed. She could not move to her daughter in Olsztyn due to the cramped housing conditions that prevailed there. Her meagre pension meant that in winter, because she could not afford coal, she hardly ever heated her flat and spent the freezing period in bed almost all of the time. Other neighbours took no interest in her; they did not acknowledge her and treated her as "something inferior". The author ended his report by writing that:

As I left, I imagined Regina, wrapped in a thick rustic shawl, a leftover from years long past, going out onto her balcony to look enviously on the family travails that were being played out in the brightly lit windows. There, behind the windows, it is warm, bright and bustling. People unite in love, work, and duties; they would give others a piece of themselves and in return get a piece of someone else. Here, on the balcony, it is terrifyingly cold and empty. ${ }^{45}$

This heartrending 1960s picture of lonely old age can be supplemented if only by the reports depicting the dramatic fate of the charges of the careers of the social services that were set up at the time. ${ }^{46}$

\section{CONCLUSIONS}

Such commentaries on the interdependence between old age and poverty in Poland in the years 1945-1989 allow one to formulate several general conclusions.

Research into this problem area to date is insufficient, being concentrated chiefly (though not exclusively) on analyses of the material situation of old age and disability pensioners which stemmed from the needs

45 J. Lovell, Staruszki z zapatkami, [in:] J. Lovell, Bunt brzydulek : reportaże, Warszawa 1965 , p. 88 et seq.

46 Opiekunowie, [in:] B. Tryfan, Ziemia..., p. 99 et seq. 
of those in government who were charged with the further reform of the social security system.

The decrease in the social scope of old age poverty in PRL occurred primarily as a result of the universalisation of the pension system and the increases in benefits. In consequence of these decisions, in the latter half of the 1970s, the indicators for families of pensioners living below the poverty line, reached their lowest points. The high-point of material destitution affecting elderly people came in the period 1945-1956, particularly in the immediate post-war years.

Sociological and statistical research conducted from the 1960s, allow one to draw conclusions on how that poverty in old age impacted their household expenditure and housing conditions.

The surviving source materials allow one to analyse the world of emotions and - further - the daily routines of old people in conditions of deprivation. Such insights are provided by their numerous letters and complaints sent to the centres of power in Warsaw, or as tracked in popular journalism, particularly in special reports.

One of the most important, though completely neglected, problems is the fate of elderly people deprived of any sort of income, sometimes without roofs over their heads, living on the margins of society; that is why they seldom represented a subject of interest for the state. Information on them should be sought primarily in the documents of social care institutions that operated in PRL (Caritas, the Central Committee of Social Security, the Polish Committee of Social Aid and others), as well as the services operating as part of the state administrative structures. Defining the scale of incidence of this group and its modes of existence is a difficult but necessary field of study.

Dariusz Jarosz - Professor of History at the University of Warsaw and the Polish Academy of Sciences. Scientific interests include the history of Poland after 1945 and relationships with Western countries. Selected books include Wkrzywym zwierciadle. Polityka władz komunistycznych w Polsce w świetle plotek i pogłosek z lat 1949-1956 [Through a Distorting Mirror. The Image of Polish Communist Authorities in the Light of Common Knowledge, 1995], Polacy a stalinizm [Poles and Stalinism 1948-1956], and Mieszkanie się należy... Studium $z$ peerelowskich praktyk spotecznych [Apartment to be... Study of social practices in Polish People's Republic, 2010]. 